\title{
The Effectiveness of Commercial Banks' Credit Appraisal Techniques in Improving Asset Quality.
}

\author{
Patience ChidoMakomeke ${ }^{1}$, ChipochedengaMakomeke ${ }^{2} \&$ Miriam Chitura $^{3}$
}

\begin{abstract}
Commercial banks have constantly reported deteriorating asset quality due to non-performing and defaulting loans.Losses turn from outright default due to inability or unwillingness of customers or counterparties to meet commitment in most banking institutions. The purpose of the study was to identify various causes and the debilitating repercussions of poor credit risk management, various credit appraisal techniques, and implementation of these techniques in Zimbabwean commercial banks.It also sought to identify causes of deteriorating asset quality as well as their effectiveness, paying particular attention to asset quality.The researchers employed an exploratory researchdesign. Results indicated that concentration risk was evenly spread across all sectors stipulated by the Reserve Bank of Zimbabwe hence the concentration risk of the banking institutions is fairly low. However, the concentration risk ratio in relation to public sector lending and private sector lending was concluded to be very high and most banks' loans are heavily weighted towards the public economic sector. Insider borrowing in commercial banks is relatively high as some banks are exposed to as much as $30 \%$ of their total loan book.In light of the findings, the following conclusions were made that, all commercial banks in Zimbabwe use credit appraisal techniques when establishing the credit worthiness of borrowers and there is a direct relationship between these techniques and asset quality. Most commercial banks worldwide employ a number of credit appraisal techniques when assessing the credit worthiness of a prospective borrower and this is meant to assist in improving loan quality. Research findings also indicated that, the internal rating system is one of the most common and effective credit appraisal technique employed by every commercial bank in Zimbabwe and is an important tool in credit risk management.
\end{abstract}

Keywords: credit appraisal, defaulting loans, credit risk management

\section{Introduction}

Deteriorating asset quality mainly due to non-performing and defaulting loans has been constantly reported, for the past few years, by commercial banks in Zimbabwe. Losses turn from outright default due to inability or unwillingness of customers or counterparties to meet commitment in most banking institutions. Alternatively, losses mainly result from reduction in portfolio value due to actual or perceived deterioration in asset quality. Since commercial banks are in financial arbitrage, that is, mobilizing money from depositors and lending it to borrowers at an interest, there is also need for sound and good credit appraisal. Consequently, prudent lending is very necessary if the bank wants to retain its integrity guaranteed in the market, and the market to have confidence in it. The purpose of the study wasto identify various causes and the debilitating repercussions of poor credit risk management, various credit appraisal techniques, and implementation of these techniques in Zimbabwean commercial banks.It also sought to identify causes of deteriorating asset quality as well as their effectiveness, paying particular attention to asset quality.

\section{Background to the Study}

Banks in Zimbabwe are exposed to such risks asCredit liquidity, market price, interest rate risks to name but a few. The complexity of these risks has been heightened by technological advancement, financial innovation as well as the economic meltdown in Zimbabwe. Failure to adequately manage these risks exposes banks not only to the possibility of losses, but more importantly to the possibility that they may not achieve their strategic business objectives. In some instances, inadequate risk management may result in circumstances so catastrophic that the institutions cannot remain in business.

The Zimbabwe banking system, the financial services sector and the economy in general has been hit by a series of failing businesses due to a number of factors which include, among them, poor credit risk management practices. Several government sectors, including the Health Care sector, were severely affected by the deteriorating economy. Home Based Care (HBC) became an alternative strategy to cope with the worsening burden of disease especially from the Human- immunodeficiency Virus (HIV) victims.

\section{Statement of the Problem}

In 2004, Zimbabwe saw the collapse of a number of banking institutions. Several conclusions were made by the Reserve Bank of Zimbabwe including the fact that, failing banking institutions had large proportions of non-performing loans and defaulting loans resulting in deteriorating asset quality which is 
statistically a significant prediction of insolvency. Annual consolidated reports by various commercial banks as well as Global Credit Ratings reports on commercial banks in Zimbabwe reported on the deterioration in aggregate asset quality with gross non-performing loans and defaulting loans increasing. The ZB Bank for instance in its financial report as at half year ending 30 June 2012 reported a decrease in asset quality with the capital value in arrears defined as loans greater than 90 days in arrears increasing by $7.8 \%$. The deteriorating loan quality had the greatest impact on the industry earnings as institutions continued to set aside reserves to cover loan losses, hence affecting overall profit margins.

\section{Objectives of the Study}

- To analyze the effectiveness of credit appraisal techniques employed by banks in improving asset quality.

- To analyze the causes of deteriorating loan quality in Zimbabwean commercial banks.

- To find out the benchmarks that are used by commercial banks in determining asset quality.

- To assess the importance of using credit appraisal techniques in improving loan quality as well as credit risk exposure.

- To examine the impact of this deterioration on other sectors including the Health Care sector

Research findings are likely to be of great benefit to financial institutions particularly commercial banks, prospective individual borrowers and corporate clients as well as all other economic players who are directly and indirectly beneficiaries of bank lending in Zimbabwe. This research will also add to the collection of existing empirical studies in order to give future researchers as well as readers on the topic an understanding of the subject at hand.

\section{Some assumptions:}

- Timely responses will be obtained from interviewees.

- Those participating in the research understood credit risk management

- Accurate, reliable and relevant information is obtainable.

- Findings are generalizable to the financial sector.

\section{Definition of terms}

Non-Performing loan is a loan that is not earning income because full payment of interest or principal is no longer anticipated or the maturity date has passed and payment in full has not been made. The non-performing loan ratio is our primary indicator of loan quality problems.

Asset quality refers to level, distribution, trend and severity of asset classifications, the level, composition, and trend of past due, non-accrual, and non-performing loans, the adequacy of provisions for bad debts and the demonstrated ability to administer and collect problem credits and general economic environment.

Commercial bank is a banking institution involved in taking depositors' funds and investing them and also issues out loans to corporate and individual borrowers.

Credit appraisal techniques are methods that are employed by commercial banks when assessing the credit worthiness of a prospective borrower. These techniques usually vary, depending on determinants such as the size and maturity of the loan, the operating record of the business, security offered and previous relations with the borrower.

Credit risk is the current or prospective risk to earnings and capital arising from an obligator's failure to meet the terms of any contract with the bank or if an obligatorotherwise fails to perform as agreed.An institution is exposed to credit risk from diverse financial instruments such as loans, acceptances, inter-bank transactions, trade financing, foreign exchange transactions, financial derivatives and other off-balance sheet activities.

Risk management framework encompasses the scope of risks to be managed, the process/systems and procedures to manage risk and the roles and responsibilities of individuals involved in risk management.

Credit policy is a guideline on overall credit operations within a banking institution to ensure the establishment and maintenance of proper credit standards within the bank.

Although some of the findings of this research may apply to many countries world-wide especially developing economies, the study was carried out based on the data from commercial banks in Harare, Zimbabwe. Gathering of data was limited to relevant sources under commercial banks, and most of the information upon which the study was based were sourced from Risk and Compliance, Corporate Banking and Micro finance departments.

\section{Limitations}

- The researchers faced numerous challenges in the process of carrying out the study. These included limited time and resources, hence the researchersfailed to thoroughly explore the impact on many government sectors such as Health Care.

- Some bank employees may not have given accurate information in order to maintain institutional confidentiality. 
- Data collection processtook more time than anticipated due to delayed responses.

The researchers carried outa review of literature, with regards to credit appraisal techniques being employed by commercial banks, causes of deteriorating loan quality, loan quality issues, benchmarks for loan quality as well as the importance of these credit appraisal techniques in improving loan quality. The literature review was mainly based on empirical and theoretical evidence so it looked at what various scholars in their textbooks say about the effectiveness of appraisal techniques in relation to improving asset quality.

Work by various journalistic writers and published research work was incorporated in order to identify the effectiveness and importance of credit appraisal techniques employed by commercial banks. Case studies of banking institutions in Zimbabwe and other international banks were also examined as empirical evidence.

Credit appraisal techniques are employed by commercial banks worldwide when assessing the credit worthiness of a prospective borrower. The techniques are meant to assist in improving loan quality. Reed and Gill (1989:122) outlined that the credit appraisal processes usually vary, depending on determinants such as the size and maturity of the loan, the operating record of the business, security offered and previous relations with the borrower. Outlined below are various appraisal techniques that are employed by local commercial banks in Zimbabwe and worldwide.

\section{Internal Risk Rating System (IRRS)}

Local banks have adopted the rating systems by developing internal risk rating systems, over the years, since there is significant probability that some borrowers will default and that some reserves should be held against these loans. Crouhy, Galai\& Mark (2006: 232) highlighted that the internal risk rating system mainly looks at how banks arrive at their own private internal rating of firms, both large and small that lack a public credit rating. They further outlined that internal risk rating systems are one of the banking industry's oldest and most widely used credit-risk measurement tools. However, practices are fast changing as a result of both regulatory and competitive pressures. Internal rating systems allow the analysis of thousands of borrowers within a consistent framework and permit comparisons across the entire loan portfolio. Large banks use these internal ratings in several critical aspects of credit-risk management, such as loan origination, loan pricing, loan trading, credit portfolio monitoring, capital allocation and reserve determination, profitability analysis, and management reporting. The Bankers' Guide to Basel II framework (2004: 32) highlighted that internal risk rating systems are such a key element of the credit risk management systems of financial institutions. That is why they are at the center of the new Basel II regulatory capital attribution process. It further outlined that a bank's internal risk rating system and the associated probability of default (PD) and loss given default (LGD) statistics will be key inputs into the new regulatory capital calculations, hence banks will be able to use their own internal risk rating systems to set credit risk capital requirements.

\section{Purpose and Benefits of using Internal Rating System}

Crouhy et al (2006: 234) outlined that internal risk rating systems are used by financial institutions for a variety of purposes. This includes the following:

- Pricing and trading of loans. Internal ratings are key inputs for credit portfolio models, from which the risk contribution of each facility in a credit portfolio can be derived. In turn, these risk contributions help determine the minimum spread that an institution should charge on a credit facility in order to factor in the cost of credit risk.

- Setting limits and acceptance or rejection of new transactions. The strength of the rating awarded to an entity or transaction is likely to play a key role in the decision to accept or reject a particular transaction.

- Adequacy of capital. Again, both regulators and management, and also rating agencies, use the portfolio risk profile, as measured by internal ratings, to judge the fundamental creditworthiness of an institution.

- Monitoring of credit quality. Ratings should be reviewed periodically, at least once a year or if a specific event justifies the revision of the credit assessment of a borrower. Credit migration is a critical component in monitoring the credit quality of the loan portfolios of banks.

- Adequacy of loan loss reserves. Both regulators and management use the distribution of portfolio quality, as measured by internal ratings, to judge the adequacy of the financial accounting-based reserve for loan losses and the provision for losses in the current accounting period.

- Attribution of economic capital. Best-practice institutions will have a Risk adjusted Return on capital (RAROC) system in place to assess the contribution to shareholder value of the firm's activities and portfolios.

\section{Calculating Internal Risk Ratings}

Tracy, Carey (2000: 212) discovered that typically, a bank IRRS assigns two kinds of ratings. First, it assigns an obligor default rating (ODR) to each borrower (or group of borrowers) that identifies the borrower's 
probability of default and secondly, it assigns a loss given default rating (LGDR) to each available facility, independently of the ODR, that identifies the risk of loss from that facility in the event of default on the obligation. The two further highlighted that, the ODR represents simply the probability of default by a borrower in repaying its obligation in the normal course of business. The LGDR, on the other hand, assesses the conditional severity of the loss, should default occur. The severity of the loss on any facility is considerably influenced by whether the bank has put in place risk mitigation tools such as guarantees, collateral, and so on.

On the other hand, Kingdom Bank Credit policy manual (2005: 24) outlined that risk rating is the combination of two components:

- The risk of default (called "Client Quality Classification" or CQC). This is a measure of the client's strength.

- The loss severity arising should default occur (called "Security Classification"). This is a measure of the loss if all security held had to be liquidated to repay the facility.

Together, these components generate an expected loss rating on the credit risk rating matrix to give a credit risk rating. The credit policy manual further on highlighted how the Credit Quality Classification and the Security Classification are calculated.

\section{Credit Quality Classification}

In this process, the client quality score card is used. This scorecard is used to determine the need for the Group to provide for the debt in part or full, and /or reserve interest. The CQC seeks to provide an accurate picture of the current status of the company hence the bank should therefore have a sound understanding of the customer's business.

\section{Security Classification}

This component looks to see how much of the bank's exposure is covered by security. In this case the bank will merely try to discover how many times security held is likely to cover the facilities being provided at this moment in time under current conditions.

\section{Expert Systems}

Expert systems are commonly used by most local banking institutions in Zimbabwe. Reel andGill (1989: 243) outlined that expert systems are basically traditional approaches to credit risk management and mainly include CAMPARI, PAPERS, IPARTS and 5Cs. The two further outlined that, in this approach, the credit decision is left to the local branch lending officer or the accounts relationship manager. Implicitly, this manager's expertise, subjective judgment and weighting of certain key factors are the most important determinants in the decision to grant credit. Once a client has been visited and a visitation report complied, the lender should now proceed to prepare a credit proposal using the traditional approaches.

\section{Causes of deteriorating Asset Quality}

According to the Reserve Bank of Zimbabwe financial stability report (2014: 21), the asset quality of the banking sector deteriorated during the period ending 31December 2013, as reflected by the decrease in the ratio of adversely classified loans to total loans, from $13.78 \%$ as at 31 December 2012 to $15.34 \%$ as at 31 December 2013. The increase in the ratio is partly a reflection of a deterioration of asset quality, high lending rates and high default rates. According to the stress tests conducted by the Reserve Bank of Zimbabwe on the Zimbabwe's banking sector, the main causes of the deteriorating asset quality included High level of nonperforming loans, Large exposures to a single borrower or group of related borrowers, High prevalence of connected and insider loans, Weak internal credit control systems, Inadequate provisions for loan losses and other asset valuation reserves.

\section{Benchmarks or Measures for Loan Quality}

According to Comptroller handbook: Allowance for loan lease losses (1998: 34), most banking institutions use asset quality ratios as a benchmark for loan quality or as a way to measure loan quality. The asset quality ratios reflect the quality of banks' assets in terms of over-exposure to specific risks, trends in nonperforming loans and the health and profitability of bank borrowers.

\section{Importance of Credit Appraisal in Improving Loan Quality}

Credit appraisal remains at the heart of the decision making process leading to the granting of credit to a borrower. Yoori Je Cho (1989: 12) pointed that banks experience problems with non-performing loans (NPLs) due to weak credit analysis. He further highlighted that the purpose of credit appraisal is to help the bank make 
good credit decisions and helping the bank avoid making incorrect decisions. Reed and Gill (1989: 122) argued that the objective of credit appraisal is to determine the ability and willingness of the borrower to repay a requested loan in accordance with the terms of a loan contract.

Reckless credit appraisal will not only jeopardize the bank, but depositors and investors. Prudent lending is very necessary if the bank wants to retain its integrity guaranteed in the market and the market to have confidence in it. Bessie (2002: 103) highlights that, when properly applied, credit risk management techniques have the potential of increasing an organization's profit over a period by minimizing losses.

\section{Methodology}

The researchers employed an exploratory research design. This design was adopted because it provided the investigators with a better idea and insight about a broad and vague research problem as the study sought to identify and evaluate the effectiveness of credit appraisal techniques in improving asset quality.

Causal research design method was also considered appropriate in this research as it sought to identify the effect of credit appraisal techniques in relation to improving asset quality. Causal research involves the determination of factors that relate to the variables to be analyzed and seeks to establish the cause of the relationship between or amongst variables. This was used as the researchers sought to find if effective credit appraisal resulted in an improvement in banks' asset quality.

\section{Target population}

The target population included commercial banks' credit analysts, risk managers, account relationship managers, credit committee members, risk management department heads and corporate bankers. The Reserve Bank of Zimbabwe was also considered as the part of the population for they perform the role of supervision, surveillance and regulatory authorities in the commercial banks. There were sixteen commercial banks operational in Zimbabwe and the seventeenth bank was the Reserve Bank of Zimbabwe at the time of the study.

\section{Sampling techniques}

Stratified random sampling was the main sampling technique used by the researchers. The researchers allocated every commercial bank in Zimbabwe a number until all the banks had numbers to represent them. The papers with the numbers were put in a box and these were picked randomly until the targeted population was reached. The sample was representative and not biased. Since a given unit (commercial bank) was chosen only once, this strategy is an example of sampling without replacement.

The researchers also used judgmental sampling thus the selection of the sampling units was consciously shaped by the researchers' agenda. Judgmental sampling was used for the selection of credit and corporate analysts, credit and corporate managers and heads of departments. The basis of the target population was based on the subjective instinct that those members would represent the entire group. This sampling technique was used because it is convenient, fast and relatively cheaper and conclusive judgments could be made on the work under the study.

\section{Sample size}

Ten commercial banks were chosen out of the sixteen currently operational commercial banks in Zimbabwe. The commercial banks were independently selected one at a time until the desired sample size of ten was achieved. Each commercial bank in the finite population had an equal chance of being included in the sample. The population of commercial banks is sixteen and the probability that a particular bank was chosen was 0.625 , which meant that, it was close to certainty. The $\mathrm{n} / \mathrm{N}$ formula by Pagano and Gauveau $(2000 ; 515)$ was used where $\mathrm{N}$ presents the size of the total population and $\mathrm{n}$ represents the size of the sample. The sample size chosen achieved cognizance of almost every element in the population for it achieved 63\%. The sample can be considered to be an objective illustration of the target universe.

\section{Primary data collection methods}

Primary data was collected by means of a survey based on questionnaires and interviews. This was because questionnaires can produce large quantities of highly structured and standardized data. They also allow for free style of investigation, and pursuing particular issues in greater detail. Some of the questionnaires were administered through e-mail. E-mail allows the respondent to fill it out at their own convenience. It was relatively quick to collect information using questionnaires and it was possible to collect information from a large portion of the sample population.

Interviews were conducted in a structured form to ensure consistency. An interview schedule was used. Both personal and telephone interviews were conducted. Structured interviews were more flexible and enabled the researchers to have control over the respondents so as to meet the researchers' objectives of the study. 
Secondary data collection methods were used in-order to complement primary data by analyzing data that already existed from published sources like text books, journals, the internet and RBZ framework manuals, commercial bank's manuals and other reports. Main secondary data sources used includedtextbooks, Journals and the Internet. The internet was the most valuable source of information in this research. It provided data for both theoretical and empirical literature review. It was a source of most recent developments in local and global commercial banks.

\section{Data presentation and analysis procedure}

Both qualitative and quantitative techniques were used to analyze the data gathered in the administration of the research instruments pointed above. Qualitative analysis was used on the data collected through secondary data gathering and phrases in personal interviews. On the other hand, there was quantitative analysis of questionnaire responses through the use of descriptive statistics, as well as variables such as frequencies, averages and ranges. Quantitative data analysis was used to statistically uncover associations from the findings, trends and patterns.

Qualitative analysis was done throughparaphrasing and summarizing responses, classifying responses into categories and content analysis. Patterns were noted and conclusions drawn.

The use of tables and charts with percentages was done with the help of Microsoft Excel Software to enable wide data to be condensed into few manageable tables for further analysis. This facilitated comparability, where necessary, with recommendations for good practice and comparison with available statistics of practices in commercial banks in other countries.

\section{Results}

The results of the analysis were presented diagrammatically and expressed in percentages for easy assessment. Bar charts, pie charts, column graphs, tables and doughnut charts were employed to present the findings of the research. The researchers basedtheir conclusions mainly on analysis of results.

\section{Questionnaire Response Analysis}

Out of the twelve questionnaires sent to the commercial banks fully operational in Zimbabwe, ten were returned fully completed. Thus, the research attained an $83.3 \%$ response rate with $60 \%$ of the respondents being corporate and risk managers, $20 \%$ being credit analysts, $10 \%$ being senior credit analysts and the remaining $10 \%$ being heads of departments. Thus the findings are from ten commercial banks, namely Barclays Bank, Steward Bank, NMB Bank, BancABC,Stanbic Bank, MBCA Bank, Met Bank, Kingdom Bank, ZB Bank and FBC Bank.

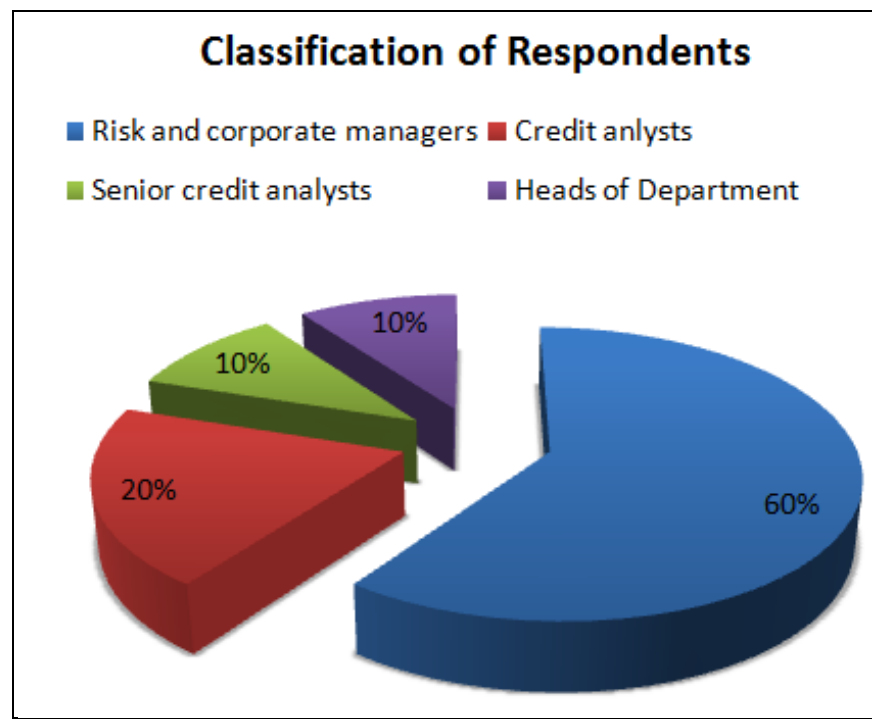

Figure1: Classification of Respondents on Questionnaires

\section{Interview Response analysis}

Out of the six interviews the researchers had targeted, five were successfully conducted with five of the selected commercial banks. Thus, the research attained an $83,3 \%$ response rate with $40 \%$ of the respondents being corporate and risk managers, $40 \%$ being credit analysts, $20 \%$ being senior credit analysts. No interviews were conducted with the heads of departments. The findings are from five commercial banks, namely Barclays Bank, Steward Bank, Stanbic Bank, MBCA Bank and Kingdom Bank. 


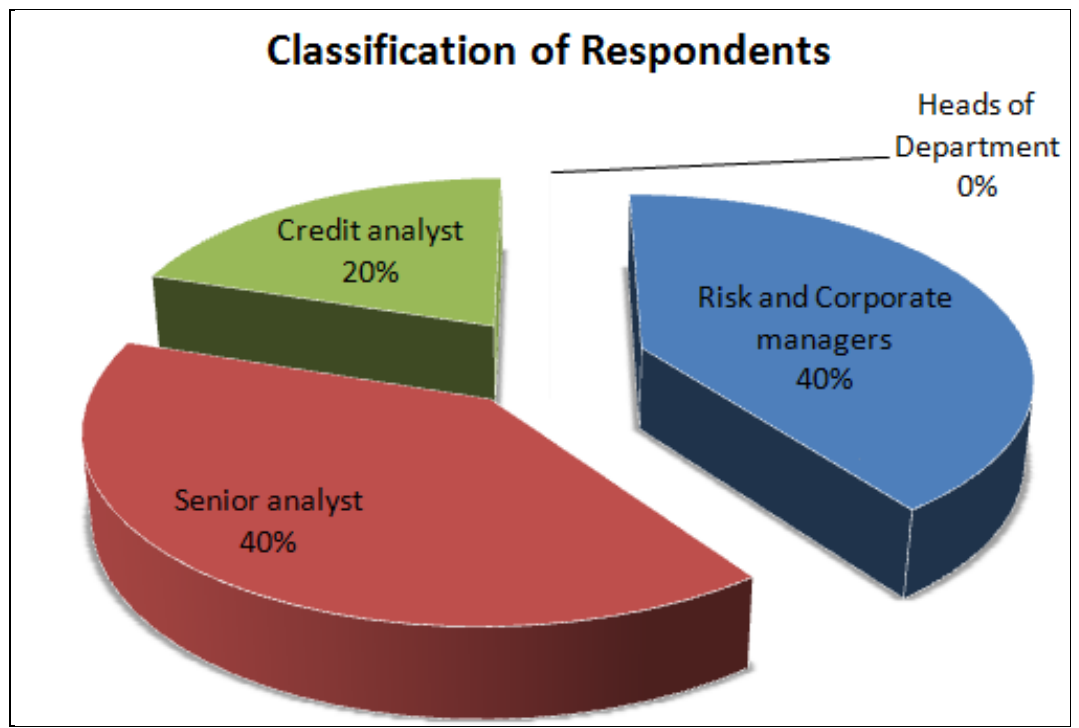

Figure 2: Classification of Respondents on Interviews

\section{Credit appraisal techniques used by commercial banks}

One of the main objectives of the study was to establish the credit appraisal techniques that are currently being used by commercial banks in Zimbabwe to assess the credit worthiness of a borrower in a bid to improve loan quality. On this note, the researcher found that the most used credit appraisal technique by Zimbabwean commercial banks is the internal rating system. An analysis on whether commercial banks have an internal rating system, showed that all banks under study use an internal rating system as one of their credit appraisal techniques. However, $80 \%$ of the respondents showed that their internal rating system is fairly effective, while $20 \%$ concluded that their system is very effective.

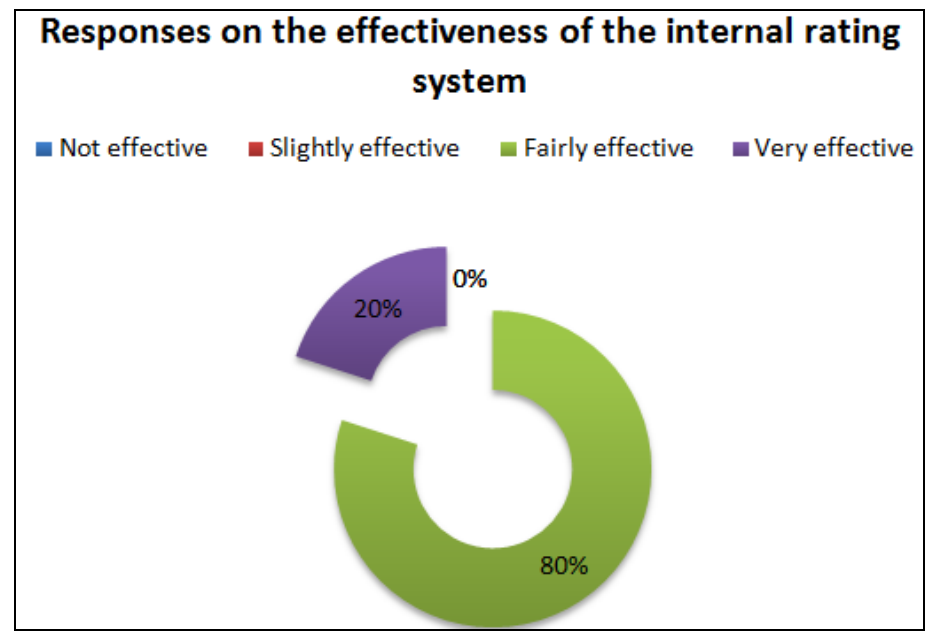

Figure 3: Effectiveness of internal rating system

Besides the internal rating system commercial banks also use other techniques when establishing the credit worthiness of a prospective borrower. From the figure overleaf, it can be seen that all the credit appraisal techniques that were provided in the questionnaire are used by the commercial banks. Two of the commercial banks under study actually use all of the appraisal techniques that were highlighted in the questionnaire. The most used techniques are the credit scoring models, thus eight of the ten commercial banks use these models when establishing the credit worthiness of a borrower. Out of the ten banks, seven, thus $70 \%$ of the banks also confirmed to be using the $5 \mathrm{Cs}$ as a credit appraisal technique. However, Papers is the least used appraisal technique as it had a $40 \%$ response. MBCA Bank also highlighted that besides the credit appraisal techniques given in the questionnaire, it also uses financial statements of the borrower when assessing credit worthiness while Stanbic highlighted that it also uses artificial neural network. The graph overleaf clearly shows the credit appraisal techniques responses from the ten banks under study. 


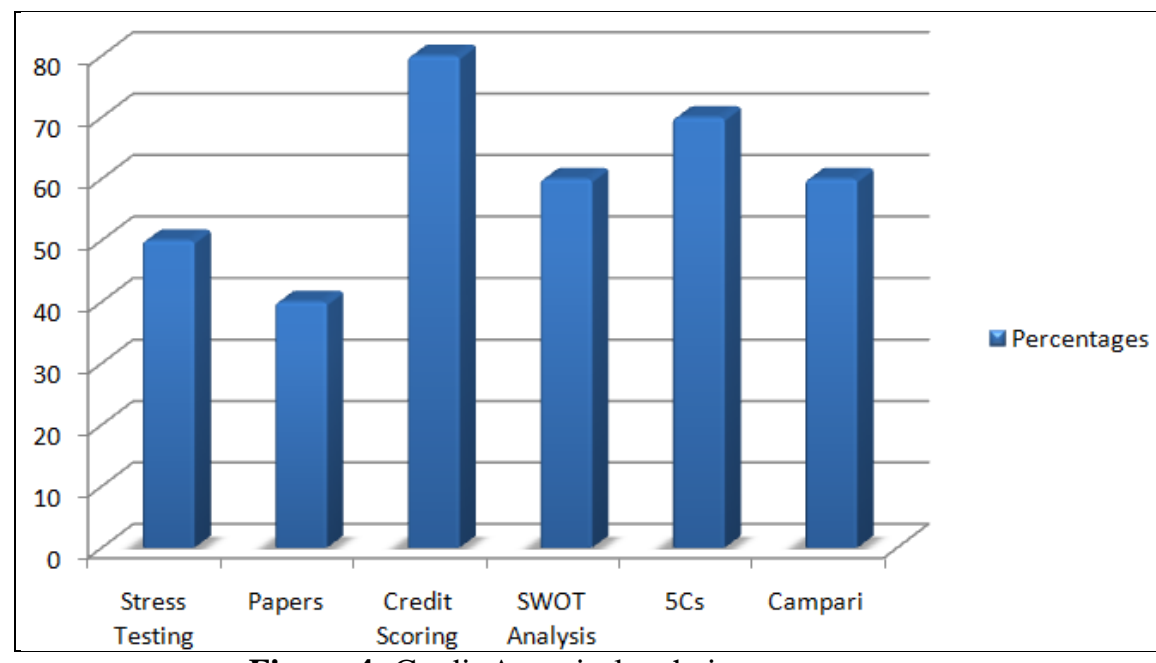

Figure 4: Credit Appraisal techniques responses

\section{Causes of deteriorating asset quality}

All the respondents under study agreed that ineffective credit appraisal is one of the major causes of non-performing loans thus creating asset quality problems. All questionnaires and interviews responses showed that all respondents highlighted that one of the major causes of deteriorating asset quality is ineffective credit appraisal. Since they were no disagreements to the above sentiments, the researcher noted that ineffective credit appraisal is one of the major causes of non-performing loans thus creating asset quality problems.

However, the ten commercial banks under study also came up with a number of other causes for non-performing loans and defaulting borrowers:

- Lack of timeous follow-ups on payment defaults. Steward Bank noted that usually follow up is only instituted beyond the sixty day age analysis.

- Market liquidity and volatile market conditions were also highlighted as one of the major causes of nonperforming loans and defaulting borrowers. The respondents outlined that generally the market is facing serious liquidity problems as every sector in the economy is chasing after the scarce united-states dollars.

- Inadequate client tracking for applications of borrowed funds. Banks do not adequately track the client's application for borrowed funds, hence might advance to a client without a client visit for instance.

- External competition was also noted as one of the main causes for non-performing loans, it was outlined that many banks are facing strong competition from external markets.

- Weak internal credit control systems were also highlighted as one of the main causes of non-performing loans and defaulting clients. The lack of adequate credit documentation and the timely identification and collection of problem loans has generally resulted to defaulting borrowers.

- Poor working capital management by the borrowers has also been outlined as another cause of nonperforming loans. It has been noted that clients generally lack the expertise of designing an effective cash flow hence resulting in default of the client.

The recent Reserve Bank of Zimbabwe financial stability report (2014: 21), showed that the asset quality of the banking sector deteriorated during the period ended 31December 2013, as reflected by the decrease in the ratio of adversely classified loans to total loans, from $13.78 \%$ as at 31 December 2012 to $15.34 \%$ as at 31 December 2013. The increase in the ratio is therefore a reflection of a deterioration of asset quality, high lending rates and high default rates.

The researcher requested the ten commercial banks under study to provide their ratios of non-performing loans to performing loans for the past three years thus from 2011 to 2013.

The banks submitted different ratios from each other for the 3 years. Some of the ratios were as low as $2 \%$ and some went up to $40 \%$. The average ratio for each bank was calculated to come up with the average nonperforming loans to performing loans ratio for the 3 years, 2011 to 2013. 


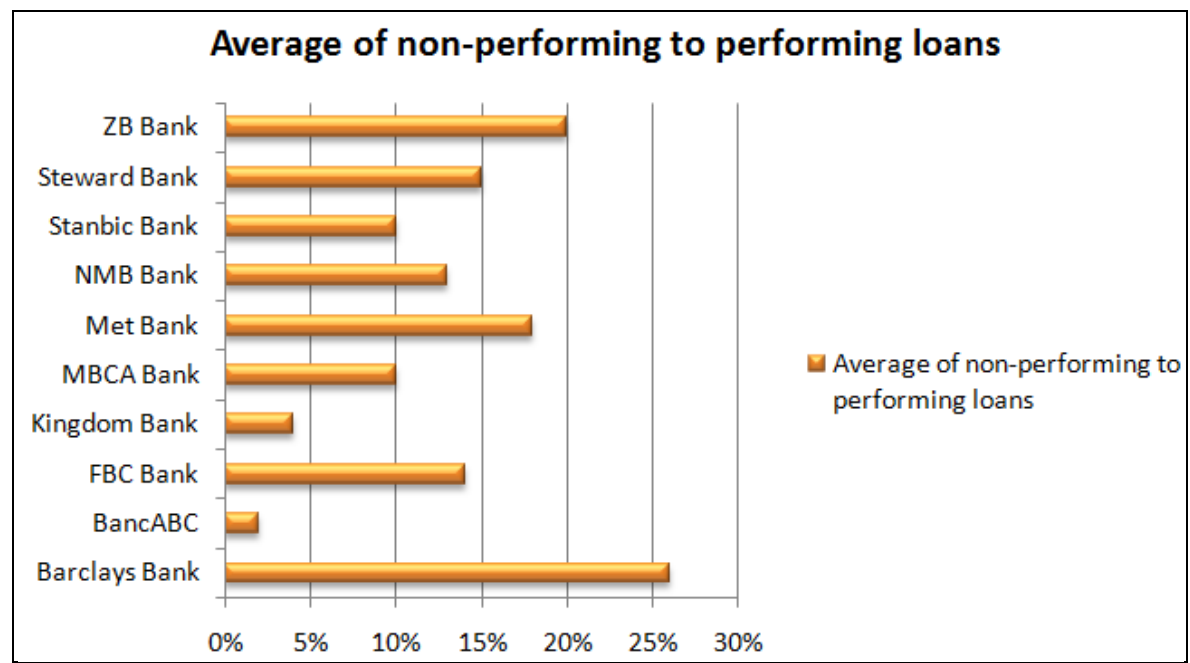

Figure 5: Average non-performing to performing loans ratios for the ten banks

\section{Large exposures to a single borrower or group of related borrowers}

With reference to guidelines from the Reserve Bank of Zimbabwe on sectorial exposures, the ten banking institutions provided their percentages of total loan book in relation to the Manufacturing, Agriculture, Mining, Tourism, Transport, SMEs\&Distribution sectors.

This particular question was researched on in order to calculate and assess the concentration risk of the banking institutions. Concentration risk denotes the overall spread of a bank's outstanding accounts over the number or variety of debtors to whom the bank has lent money. This risk is calculated using a concentration risk ratio which explains what percentage of the outstanding accounts each bank loan represents. The ratio also assists in assessing whether loans are evenly distributed or are heavily concentrated in certain economic sectors. Also, loans weighted towards a specific economic sector would create a higher ratio than a set of evenly distributed loans because the evenly spread loans would serve to offset the risk of economic downturn and default in any one specific industry damaging the bank's outstanding accounts.

Assessing the ten banks' concentration risk, it can be noted that the banks' loan books are evenly spread across all sectors stipulated by the Reserve Bank of Zimbabwe hence the concentration risk of the banking institutions is fairly low. The table below shows the mean average percentages of the total loan books in relation to the sectors given by the Reserve Bank of Zimbabwe.

Table 1 Average percentages of total loan books to economic sectors

\begin{tabular}{|l|c|}
\hline Sector & Percentage of total loan book \\
\hline Manufacturing & $23,51 \%$ \\
\hline Agriculture & $6,08 \%$ \\
\hline Mining & $29 \%$ \\
\hline Tourism & $5,6 \%$ \\
\hline Transport & $11,2 \%$ \\
\hline SME & $7,74 \%$ \\
\hline Distribution & $9,19 \%$ \\
\hline
\end{tabular}

From data obtained by the researcher it can be noted that four out of the ten banks under study do not lend to the tourism sector and three of the banks also do not lend to the Agricultural sector. The agriculture and tourism sector constitute a small percentage of the total loan composition of the banks lending to them. This is mainly due to the liquidity challenges facing these two sectors.

The concentration risk ratio in relation to public sector lending and private sector lending was also calculated for the ten banks as a whole using the average percentages of the total loan books to economic sectors. The sectors that fall under the public sector lending include manufacturing, agriculture, mining, tourism, transport and distribution whilst the small to medium enterprises sector is the only one which falls under the private sector lending. The average public sector lending to private sector lending concentration risk ratio for the ten banks under study was calculated to be $92.26 \%$. This clearly shows that the banking institutions' concentration risk is very high and their loans are heavily weighted towards the public economic sector. This high ratio shows that the loan portfolios are not evenly distributed between the public and private sectors hence commercial banks are facing the risk that if the public sector collapse in Zimbabwe, that can damage their complete loan portfolios. The figure below shows the public sector to private sector concentration risk ratio. 


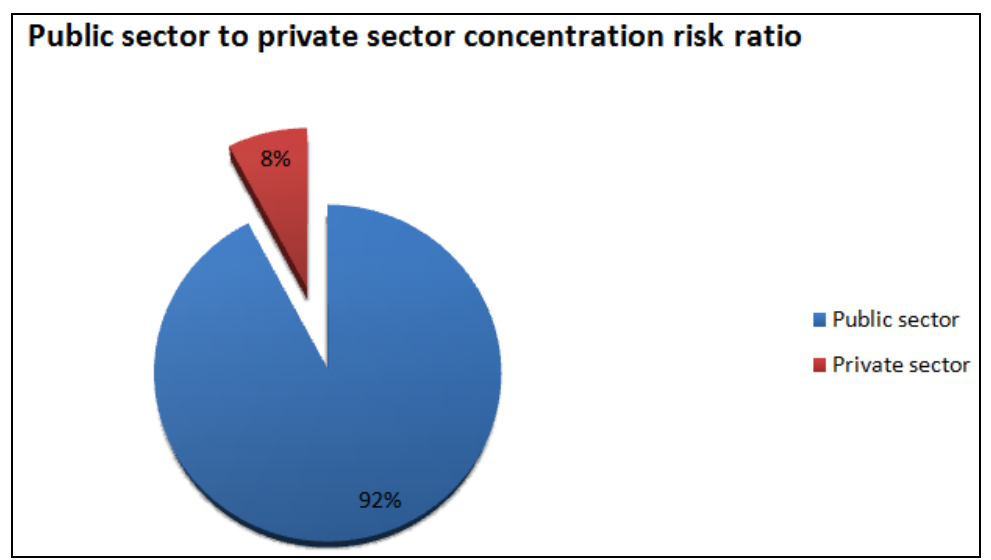

Figure 6: Average public sector to private sector concentration risk ratio

The respondents were also asked to give their opinion on which sector they view as the most profitable sector in Zimbabwe. This assisted the researcher to assess whether banking institutions are maximizing on the most profitable sectors thus lending more to these most profitable sectors. From the table 4.2 shown overleaf, most respondents view the mining sector as the most profitable sector of all economic sectors. However three of the fifteen respondents were to the sentiment that the distribution sector is the most profitable sector of all the sectors in Zimbabwe thus the distribution sector had a $20 \%$ response rate. Table 4.1 clearly shows that the mining sector had the highest average percentage of the banks' total loan books of $29 \%$. This therefore shows that most banking institutions are maximizing on this most profitable sector.

Table 2: Most profitable sector in Zimbabwe responses

\begin{tabular}{|c|c|c|c|c|}
\hline Value & & Frequency & Percent & Cumulative \\
\hline Manufacturing & 1 & 1 & $6.67 \%$ & $6.67 \%$ \\
\hline Agriculture & 2 & 0 & $0 \%$ & $6.67 \%$ \\
\hline Mining & 3 & 9 & $60 \%$ & $66.67 \%$ \\
\hline Tourism & 4 & 0 & $0 \%$ & $66.67 \%$ \\
\hline Transport & 5 & 0 & $0 \%$ & $66.67 \%$ \\
\hline SMES & 6 & 2 & $13.33 \%$ & $80 \%$ \\
\hline Distribution & 7 & 3 & $20 \%$ & $100 \%$ \\
\hline Total & & 15 & $100 \%$ & \\
\hline
\end{tabular}

\section{High prevalence of connected and insider loans}

From the 2004 turmoil, connected and insider lending has contributed significantly to the poor loan quality in Zimbabwe's banking sector. Since, a high prevalence of connected and insider loans is viewed as one of the main causes of deteriorating asset quality, the researcher found it important to ask banks to provide percentages of their total loan book that constitutes insider borrowers. The graph overleaf shows the commercial banks' percentages of their total loan book that constitutes insider borrowing. From the graph overleaf it can be seen that some banks percentages are as low as $1 \%$ whilst other are more exposed with percentages as high as $30 \%$.

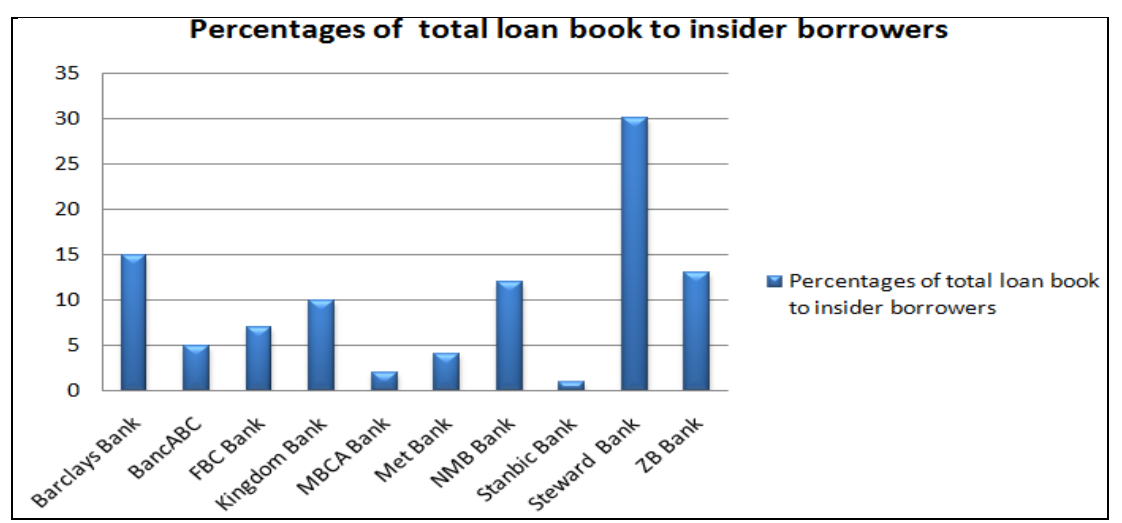

Figure 7: Percentages of total loan book to insider borrowers 
The Effectiveness of Commercial Banks' Credit Appraisal Techniques in Improving Asset Quality.

\section{Benchmarks or measures for loan quality}

Most banking institutions use asset quality ratios as a benchmark for loan quality or as a way to measure loan quality. The asset quality ratios reflect the quality of banks' assets in terms of overexposure to specific risks and trends in non-performing loans thus they determines asset quality in banking institutions. Guided by the Reserve Bank of Zimbabwe, the key asset quality ratios that are used by commercial banks in Zimbabwe to measure asset quality include the following.

$>$ Total loans to deposits ratio

$>$ Non-performing loans to total loans

$>$ Sector distribution of loans to total loans

$>$ Write offs to average total loans

$>$ Insider loans to total capital

$>$ Largest exposure to capital

Respondents were therefore requested to indicate whether they use any of the above asset quality ratios to measure asset quality in their institutions. Overleaf is a bar graph which shows the responses on which asset quality ratios the ten commercial banks under study use as a benchmark for asset quality.

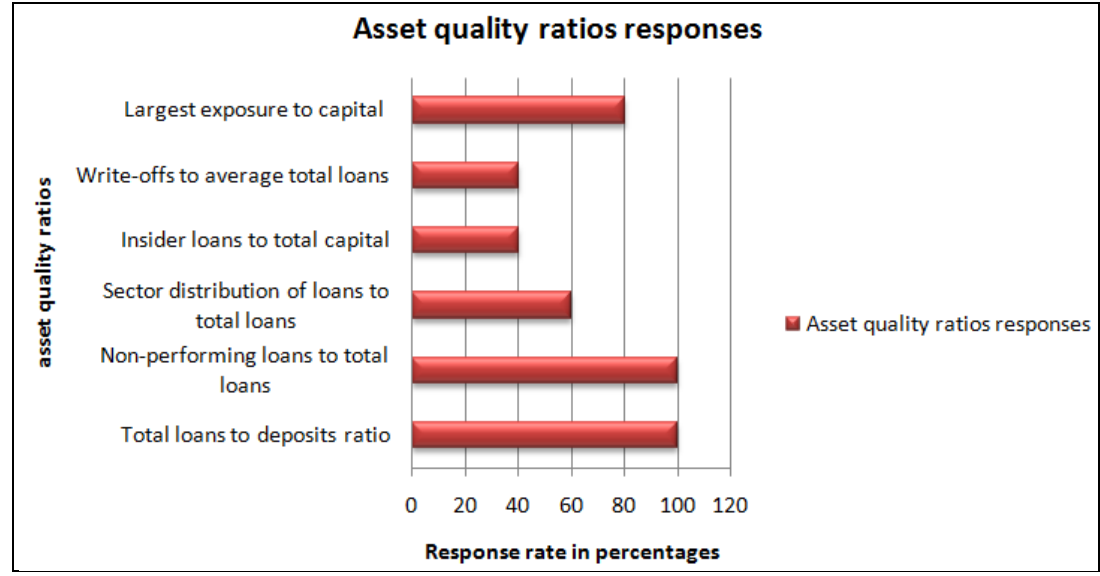

Figure 8: Asset quality ratios for commercial banks

From the graph above, it can be seen that all banking institution under study use the total loans to deposits ratio as well as the non-performing loans to total loans ratio. Most banks also make use of the largest exposure to capital ratios and the sector distribution of loans to total loans, which have $80 \%$ and $60 \%$ response rates respectively. The rest of the ratios are fairly used by the banks as they have relatively low responses rate percentages.

\section{The total loans to deposit ratio}

The total loans to deposit ratio is one of the commonly used asset quality ratio employed by commercial banks to measure asset quality in Zimbabwe. As outlined in a banking and finance Journal April 2010, the average total loan-to-deposit ratio for Zimbabwe's commercial banks in 2009 was $48.7 \%$ from about $72 \%$ in 2008 as banks slowed down on lending due to the liquidity crisis which followed after the economy was dollarized. During the first half 2009 the average loan-to-deposit ratio was $35.85 \%$. The levels are remarkably low compared to a regional average of about $75.1 \%$ recorded during the same period.

It was also noted that, Kingdom Bank has been the emblem for an industry being blamed for closing lending taps. The bank had the most attractive total loan-to-deposit ratio of $119 \%$ during the period under review. Kingdom Bank's performance was far much better than most major banks in the region. The region's loan-to-deposit ratio is said to average 109\%. The bank's total deposits during the period were US\$35.6 million. MBCA and CBZ were both on second with 67\%, Met bank 61\%, NMB 54\%, ZB Bank 42\%, Steward Bank $39 \%$, Stanbic $31 \%$, FBC 22\%, Standard Chartered $21 \%$ and Barclays $17 \%$. 


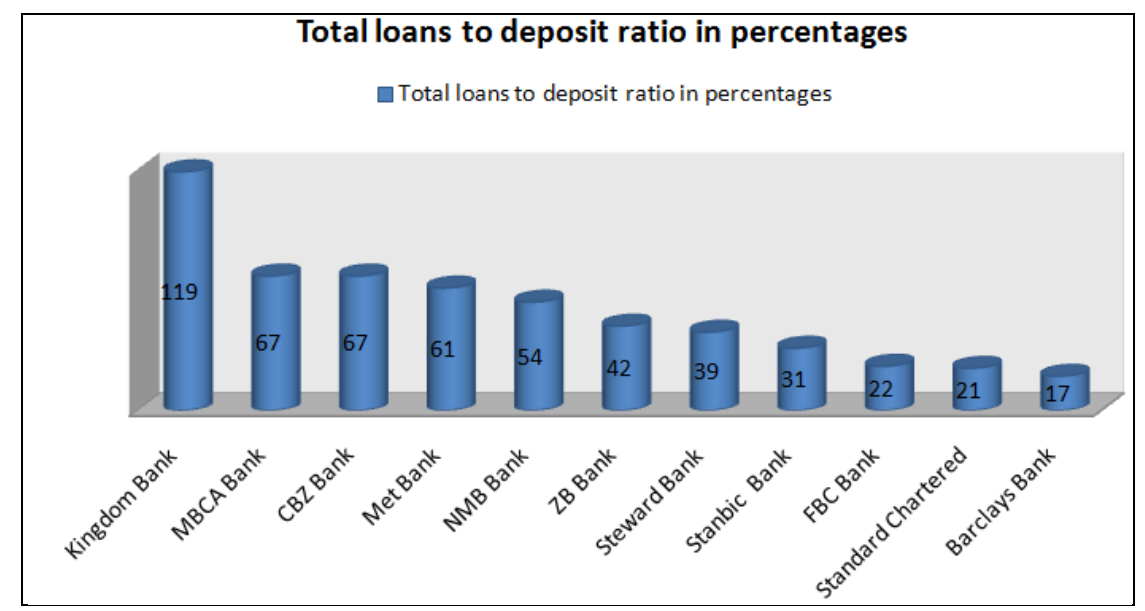

Figure 9: Total loans to deposit ratios for Zimbabwean commercial banks for the period ending 31 December 2009

Source: Banking and Finance Journal Volume 32 April 2010: Zimbabwean banks closing their lending taps

On this note, credit analysts said the extent of credit extension as at December 312009 indicated that lending had been restricted as reflected by the average loan-to-deposit ratio of $48,7 \%$. However, the quest for growth in profit by banks had often been undertaken at the expense of sound lending practices. Since the economy was dollarized, the pendulum swung too far forcing the Reserve Bank of Zimbabwe to read on banks the riot act in its monetary policy which was presented in July 2009. The Finance minister also highlighted with concern that although there was a gradual increase in the level of deposits there was no corresponding level in loans and advances and this was undermining deposits-savings mobilization and discouraging borrowings.

The minister urged all the financial institutions to play their part in the economic recovery and growth efforts by reducing the gap between deposits and lending rates as there are low interest rates of less than $0.2 \%$ on deposits against high lending rates of over $25 \%$ at some banks, coupled with other high bank charges thus discouraged savings.

\section{Usefulness of asset quality ratios}

The respondents also highlighted in their own views the usefulness of the asset quality ratios discussed above and they came up with the following:

- The ratios assist in assessing the health and profitability of bank borrowers.

- These ratios also act as robots signaling when asset quality is deteriorating or indicators for deteriorating asset quality.

- Displays the effectiveness of risk controls and balances.

- The largest exposure to capital ratio controls the bank's exposure via the capital base, thus ensuring that the largest exposure is not covering the bank's capital base. According to the Reserve Bank of Zimbabwe, a single name exposure shall not exceed $25 \%$ of the Bank's capital base while that for any group of companies shall not exceed $75 \%$. Therefore the ratio assists in managing and maintaining this prudential lending limit.

- The sector distribution of loans to total loans ratio provide statistics of which sectors are outperforming others, hence one can easily determine whether an investment in the right sector has been made.

- These ratios are useful as they can be used for comparisons with industry average hence creates awareness to management of banks with relatively poor asset quality ratios

- The ratios are used for credit rating of borrowers.

- The ratios also assist in pricing of loans.

- They offer a benchmark for recoverability of the loans advanced and gauge performance of the assets.

- These asset quality ratios are also indicators of loan performance

\section{Importance of credit appraisal in improving loan quality}

Credit appraisal remains at the heart of the decision making process leading to the granting of credit to a borrower in many commercial banks. Therefore, all the respondents agreed that the credit appraisal process is very important before availing funds to a prospective borrower thus there was a $100 \%$ response rate. They were no disagreements to the above sentiments. Consequently, it has been concluded that the credit appraisal process is very important before availing funds to a prospective borrower. 
The Effectiveness of Commercial Banks' Credit Appraisal Techniques in Improving Asset Quality.

Table 3: Frequency table for importance of credit appraisal responses

\begin{tabular}{|l|c|c|l|c|}
\hline & Value & Frequency & Percent & Cumulative \\
\hline Not important & 1 & 0 & $0 \%$ & $0 \%$ \\
\hline Slightly important & 2 & 0 & $0 \%$ & $0 \%$ \\
\hline Fairly important & 3 & 0 & $0 \%$ & $0 \%$ \\
\hline Very important & 4 & 15 & $100 \%$ & $100 \%$ \\
\hline & & & & \\
\hline Total & & 15 & $100 \%$ & \\
\hline
\end{tabular}

Since the credit appraisal process is one of the most important elements in bank lending, the researcher deemed it necessary to inquire if the credit appraisal process was guided by a company credit or loan policy and how often the policy was reviewed or amended. All the ten respondents agreed that the credit appraisal process in their banks is guided by a credit or loan policy. However, on the other note, the upper end of the investors constituting $70 \%$ of the total respondents stated that their credit policies are reviewed annually, $20 \%$ notified that their banks review their credit policies after every one to six months and the remaining $10 \%$ every two to four years. From the responses it was also noted that of the ten banks, there was not a bank which never amended or reviewed their credit policy.

\section{Effectiveness of credit appraisal techniques}

The chart below illustrates the effectiveness of credit appraisal techniques in commercial banks.

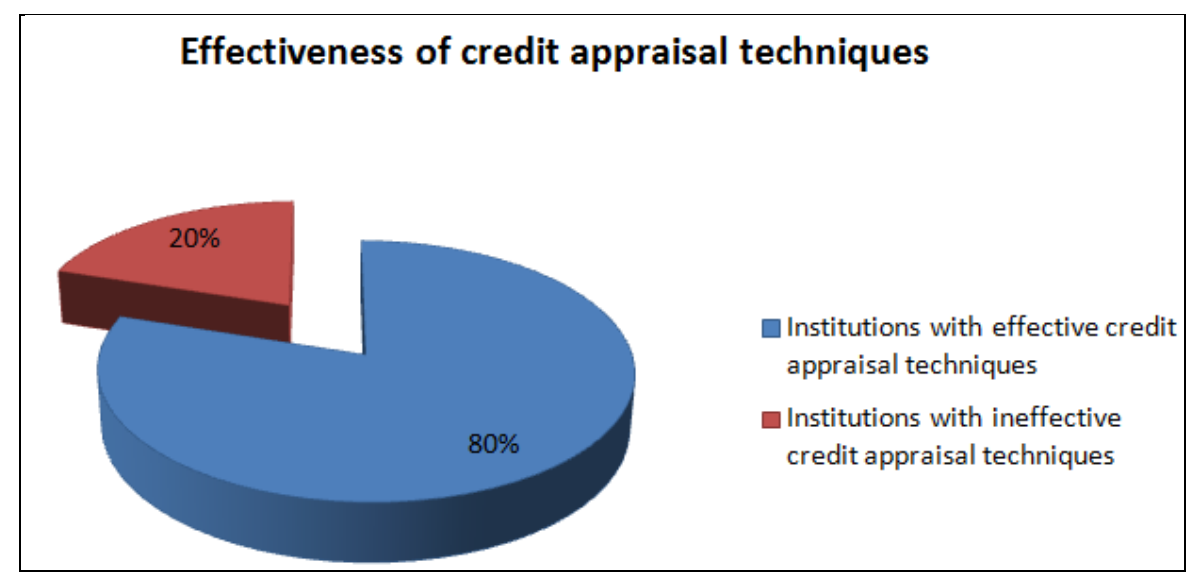

Figure 10: Effectiveness of credit appraisal techniques in commercial banks

Of the respondents, $80 \%$ concurred that their institutions have efficient and effective credit appraisal techniques that can be used to address asset quality problems. The researcher further asked the respondents to give reasons for their sentiments and some of the reasons given include the following:

- MBCA Bank highlighted that their credit appraisal techniques are very efficient and effective because their loan quality is always stable and they have limited defaults.

- Barclays Bank on the other note justified their position saying that they have tried and tested their systems and they have matched international standards since they are an international organization with learning curves from countries worldwide.

- Some of the banks outlined that they have effective credit appraisal techniques because their structures for credit assessment flow from a management level to a board level.

- Good credit rating models in some banking institutions were also given as indicators of an effective credit appraisal process.

- Stanbic Bank highlighted that their techniques looks at the past, the present and the future of the business hence this gives them a tool to understand the business from all angles.

- ZB Bank also outlined that their techniques looks at their counterparts as well as their competitors' positions hence this makes them very effective and efficient.

However, the lower class of the respondents which constituted $20 \%$ concurred that their institutions did not have efficient and effective credit appraisal techniques that could be used to address asset quality problems. The respondents gave various reasons for their sentiments. 
However, most respondentspointed that most banks experience problems with non-performing loans due to weak credit appraisal techniques. Thus, they emphasized that credit appraisal techniques werethe most effective ways of addressing asset quality problems in banking institutions.

The study examined the various credit appraisal techniques that are used by commercial banks in Zimbabwe to address asset quality problems. It was noted that most causes of non-performing loans and defaulting borrowers, leading to deteriorating asset quality are directly linked to credit appraisal techniques inefficiency. The asset quality ratios used by Zimbabwean commercial banks and their usefulness were also highlighted. The studyalso highlighted the importance as well as effectiveness of credit appraisal techniques and other ways to curb asset quality problems outside credit appraisal techniques.

\section{Summary}

This study revealed that, all commercial banks in Zimbabwe use credit appraisal techniques when establishing the credit worthiness of prospective borrowers and every commercial bank in Zimbabwe has an internal rating system in place which is effective. Commercial banks also use other techniques which include stress testing, credit scoring, SWOT analysis as well as traditional expert systems which include PAPERS, CAMPARI and 5Cs. It was also noted that although most banks stick to the credit appraisal techniques stated above, there are other banks that also use financial statements of the borrowers and neutral networks when establishing the credit worthiness of a prospective borrower.

Research findings indicated that, one of the major causes of deteriorating asset quality in Zimbabwean commercial banks is ineffective credit appraisal. Major causes for non-performing loans and defaulting borrowers which are directly linked to credit appraisal include high levels of non-performing loans, large exposures to a single borrower or group of related borrowers and high prevalence of connected and insider loans. Commercial banks in Zimbabwe have fairly high non-performing to performing loans ratios depending on the sizes of their loan books thus contributing to asset quality problems. Concentration risk was noted to be evenly spread across all sectors stipulated by the Reserve Bank of Zimbabwe hence the concentration risk of the banking institutions is fairly low. However, the concentration risk ratio in relation to public sector lending and private sector lending was concluded to be very high and most banks' loans are heavily weighted towards the public economic sector. Insider borrowing in commercial banks is relatively high as some banks are exposed to as much as $30 \%$ of their total loan book.

This study also found that, most banking institutions use asset quality ratios as a benchmark for loan quality. The key asset quality ratios that are used by commercial banks in Zimbabwe to measure asset quality include, total loans to deposits ratio, non-performing loans to total loans, sector distribution of loans to total loans, write offs to average total loans, insider loans to total capital and largest exposure to capital ratio. The total loans to deposit ratio is one of the commonly used asset quality ratio employed by commercial banks to measure asset quality in Zimbabwe. However, the total loans to deposit ratios for most commercial banks were noted to be relatively low mainly due to the liquidity crisis which followed after the economy was dollarized. The main purpose for these asset quality ratios is to act as robots signaling when asset quality is deteriorating thus they are indicators for deteriorating asset quality.

This study also revealed that, the credit appraisal process is very important before availing funds to a prospective borrower. The researchers also acknowledged that, credit appraisal process is one of the most important elements in bank lending; hence this process is guided by a company credit or loan policy which is often reviewed or amended annually. The researchers noted that, some institutions have efficient and effective credit appraisal techniques that can be used to address asset quality problems whereas other banks' credit appraisal techniques are not effective enough.

\section{Conclusions}

In light of the findings, the following conclusions were made that, all commercial banks in Zimbabwe use credit appraisal techniques when establishing the credit worthiness of borrowers and there is a direct relationship between these techniques and asset quality. Reed and Gill (1989:122) supported that when they concurred most commercial banks worldwide employ a number of credit appraisal techniques when assessing the credit worthiness of a prospective borrower. Research findings also indicate that, the internal rating system is one of the most common and effective credit appraisal technique employed by every commercial bank in Zimbabwe and is an important tool in credit risk management. This conclusion to a larger extent confirms empirical evidence by Crouhy, Galai and Mark (2006: 232) as they highlighted that most large banks use these internal ratings in several critical aspects of credit-risk management, such as loan origination, loan pricing, loan trading, credit portfolio monitoring, capital allocation and reserve determination, profitability analysis, and management reporting. Commercial banks in Zimbabwe also employ other credit appraisal techniques which include stress testing, credit scoring, SWOT analysis as well as traditional expert systems which include PAPERS, CAMPARI and 5Cs in a bid to guard against defaulting loans and non-performing loans.The 
researchers concluded that, commercial banks in Zimbabwe have fairly high non-performing to performing loans ratios depending on the sizes of their loan books, thus contributing to asset quality problems.

On assessing the commercial banks' concentration risk, it was concluded that the banks' loan books are evenly spread across all sectors stipulated by the Reserve Bank of Zimbabwe hence the concentration risk of the banking institutions is fairly low. However, the concentration risk ratio in relation to public sector lending and private sector lending was concluded to be very high and most banks' loans are heavily weighted towards the public economic sector. This indicates that the loan portfolios are not evenly distributed between the public and private sectors hence commercial banks are facing the risk that if the public sector collapses in Zimbabwe, that can damage their complete loan portfolios. This conclusion is in line with the Reserve Bank of Zimbabwe Financial Stability Report (2007: 24), which concluded that some banking institutions which accumulated large exposures to the agricultural sector found themselves in a crisis.Education and Health Sectors suffered indirect negative consequences.

Since a high prevalence of connected and insider loans was also viewed as one of the main causes of deteriorating asset quality, the researchers concluded that insider borrowing in commercial banks is relatively high as some banks are exposed to as much as $30 \%$ of their total loan books, hence this significantly affects asset quality. Duffie and Singleton (2003: 129) on the same note confirmed that most of these banking institutions with high insider borrowing disregard set prudential lending limitsto insiders.

Reed and Gill (1989: 122) highlighted that credit appraisal remains at the heart of the decision making process leading to the granting of credit to a borrower in many commercial banks. Consequently, it has been concluded that the credit appraisal process is very important before availing funds to a prospective borrower and most banks experience problems with non-performing loans due to weak credit analysis.

In Summary, the researchers concluded that commercial banks in Zimbabwe are experiencing severe deteriorating asset quality due to a number of problems facing the banks, the banking sector and the whole economy at large. Credit appraisal techniques are one of the most effective ways of improving asset quality in commercial banks. However, most banks in Zimbabwe lack effective credit appraisal techniques and undermine the capabilities of significantly reducing asset quality problems.

\section{Recommendations}

In light of the above conclusions, the following recommendations are made:

- Commercial banks in Zimbabwe should ensure that they have efficient and effective credit appraisal techniques in place as a measure of reducing asset quality problems.

- Commercial banks should test their systems before implementation and also ensure that their credit appraisal techniques match with international standards especially the credit scoring and the internal rating system.

- Every banking institution should have credit appraisal techniques that comprise methods, processes, controls, data collection and IT systems that support the quantification of default and loss estimates.

- Banks should link together or integrate their credit risk management systems with general management systems. Integration will enable risk management to respond to changing external and internal business conditions.

- $\quad$ Adopt the risk based thinking approach. This is an approach that will promote lateral thinking within banks. Risk based thinking combines a "three what's" type of approach that if used by Zimbabwean banks will ensure that their risk management practices are efficient and effective. The three "what's" are:

- What can go wrong?

- What causes it to go wrong?

- What can I do to prevent it going wrong?

Risk based thinking in banks will enable a moment's reflection before action.

\section{References}

[1] Basel Committee (2004) A Banker's Guide to Basel II Framework Banking Association South Africa, June, pp. 23-25, pp.32

[2] Basel Committee (2003) 'Sound Practices for the Management of Credit Risk', Bank Supervision, May, pp. 94-99

[3] Basel Committee (2004) viewed 11 March 2014; <http://www.creditstresstesting.com>

[4] Basle Committee (1999) 'Credit Risk Modeling- Current practices and applications', Banking Supervision, June, pp. 86-92

[5] Bessie, J. (2002). Risk Management in Banks, John Wiley \& Sons Inc., New York, USA pp. 103

[6] Comptroller's Handbook: Allowance for Loan Lease Losses (1998) pp. 26-30

[7] Comptroller's Handbook:Rating Credit Risk (2001) pp.7-8

[8] Crouhy, M., Galai, D., and Mark, R. (2006). The Essentials of Risk Management, McGraw HillCompanies, USA

[9] Davies, A., and Kearns, M.C. (1992). Banking Operations: UK Lending and International Business, $2^{\text {nd }}$ Edn, Oxford Press, London pp. $113,117,121$

[10] Duffie, D., and Singleton, K.J. (2003). Credit Risk, Princeton University Press, London pp.129

[11] Esch, L., Kieffer, R., and Lopez T. (2005) Asset and Risk Management; John Wiley \& Sons Limited, West Sussex England, pp. 234

[12] Global Credit Rating (2006) Global Credit Rating Report for Premier Banking Corporation, viewed 4 March 2014 $<$ http://www.globalcreditrating.com> 
The Effectiveness of Commercial Banks' Credit Appraisal Techniques in Improving Asset Quality.

[13] Global Credit Rating (2008) Global Credit Rating Report for African Banking Corporation, viewed 4 March 2014 <http://www.globalcreditrating.com>

[14] Greuning, H., and Bratanovi, S. B. (2003). Applying and Managing Banking Risk, $2^{\text {nd }}$ Edn, World Bank, Washington DC

[15] Henbest J. (2006). Stress Testing, Credit Risk Paper in advanced techniques on Stress Testing, IMF, Washington DC pp. 7-8

[16] Kingdom Bank (2005) Credit Policy and Procedure Manual, pp. 24

[17] Lam J. (2003). Enterprise Risk Management-From Incentives to Controls, $1^{\text {st }}$ Edition, John .Wiley \& Sons Inc., USA pp. 156

[18] Loffler, G., and Posch, P. N. (2007). Credit Risk modeling using Excel and VBA, John Wiley \&.Sons, West Sussex England, pp. 188

[19] Reed, E.W., and Gill, E.K. (1989). Commercial Banking, $4{ }^{\text {th }}$ Edn, Oxford Press, London

[20] Reserve Bank of Zimbabwe (2006) 'Risk Management', Bank Licensing, Supervision and Surveillance, BSD No// 1, pp. 43

[21] Reserve Bank of Zimbabwe (2006) 'Risk Management', Risk Based Supervision Policy Framework Guideline, BSD No// 2, pp. 15-24

[22] Reserve Bank of Zimbabwe (2014) 'Financial Stability Report', Bank Licensing, Supervision and Surveillance, April, pp. 21

[23] Reserve Bank of Zimbabwe (2009) 'Financial Stability Report', Bank Licensing, Supervision and Surveillance, November, pp. 8-9

[24] Smithson, C. (1998). Managing Financial Risk: A Guide to Derivative products, Financial Engineering and Value Maximization, $3^{\text {rd }}$ Edition, McGraw-Hill, USA

[25] Steward Bank (2013) Credit Policy and Procedure Manual, pp. 27

[26] The World Bank (2005) Handbook of Financial Sector Assessment, IMF, viewed 11 March 2014 <http://www.financialsectorassessment.com> 